AIR COMMAND AND STAFF COLLEGE

AIR UNIVERSITY

\title{
FRENCH COUNTERINSURGENCY (COIN) EFFORTS IN SPAIN DURING THE NAPOLEONIC ERA - A MODERN ANALYSIS THROUGH THE LENS OF THE PRINCIPLES OF COIN IN US JOINT DOCTRINE
}

By

Brent C. Carter, MAJ, US Army

\begin{abstract}
A Research Report Submitted to the Faculty
In Partial Fulfillment of the Graduation Requirements for the Degree of

MASTER OF OPERATIONAL ARTS AND SCIENCES
\end{abstract}

Advisor: Dr. Kenneth Johnson

Maxwell Air Force Base, Alabama

November 2014 


\section{Report Documentation Page}

Public reporting burden for the collection of information is estimated to average 1 hour per response, including the time for reviewing instructions, searching existing data sources, gathering and maintaining the data needed, and completing and reviewing the collection of information. Send comments regarding this burden estimate or any other aspect of this collection of information, including suggestions for reducing this burden, to Washington Headquarters Services, Directorate for Information Operations and Reports, 1215 Jefferson Davis Highway, Suite 1204, Arlington VA 22202-4302. Respondents should be aware that notwithstanding any other provision of law, no person shall be subject to a penalty for failing to comply with a collection of information if it does not display a currently valid OMB control number.

\begin{tabular}{|c|c|c|}
\hline $\begin{array}{l}\text { 1. REPORT DATE } \\
\text { NOV } \mathbf{2 0 1 4}\end{array}$ & 2. REPORT TYPE & $\begin{array}{l}\text { 3. DATES COVERED } \\
\mathbf{0 0 - 0 0 - 2 0 1 4} \text { to 00-00-2014 }\end{array}$ \\
\hline \multirow{3}{*}{\multicolumn{2}{|c|}{$\begin{array}{l}\text { 4. TITLE AND SUBTITLE } \\
\text { French Counterinsurgency (Coin) Efforts In Spain During The } \\
\text { Napoleonic Era- A Modern Analysis Through The Lens Of The } \\
\text { Principles Of Coin In Us Joint Doctrine }\end{array}$}} & 5a. CONTRACT NUMBER \\
\hline & & 5b. GRANT NUMBER \\
\hline & & 5c. PROGRAM ELEMENT NUMBER \\
\hline \multirow{3}{*}{\multicolumn{2}{|c|}{ 6. AUTHOR(S) }} & 5d. PROJECT NUMBER \\
\hline & & 5e. TASK NUMBER \\
\hline & & 5f. WORK UNIT NUMBER \\
\hline \multicolumn{2}{|c|}{$\begin{array}{l}\text { 7. PERFORMING ORGANIZATION NAME(S) AND ADDRESS(ES) } \\
\text { Air Command And Staff College,Maxwell Air Force Base,AL }\end{array}$} & $\begin{array}{l}\text { 8. PERFORMING ORGANIZATION } \\
\text { REPORT NUMBER }\end{array}$ \\
\hline \multirow{2}{*}{\multicolumn{2}{|c|}{ 9. SPONSORING/MONITORING AGENCY NAME(S) AND ADDRESS(ES) }} & 10. SPONSOR/MONITOR'S ACRONYM(S) \\
\hline & & $\begin{array}{l}\text { 11. SPONSOR/MONITOR'S REPORT } \\
\text { NUMBER(S) }\end{array}$ \\
\hline
\end{tabular}

12. DISTRIBUTION/AVAILABILITY STATEMENT

Approved for public release; distribution unlimited

13. SUPPLEMENTARY NOTES

14. ABSTRACT

paper attempts to portray the failures of French counterinsurgency efforts in Spain during the Napoleonic Wars in relation to US COIN tenets of understanding the Operating Environment, Unity of Command and Unity of Effort, and developing the COIN narrative. A truly effective COIN strategy encompasses a whole-of-government approach but the tenets of primacy of politics and securing the population would exceed the scope of this paper. The method of research involved a comparison of these modern COIN principles with historical examples from the time of Napoleon???s actions in Spain. At the conclusion of the research, the key findings were of no surprise. Napoleon, King Joseph Bonaparte, and his commanders in the field failed to grasp the sociocultural issues motivating the insurgents, clumsily attempted to establish unity of command that failed to achieve a unified COIN effort against the insurgency and developed a narrative that countered an effective COIN strategy. In conclusion, by comparing historical examples to modern doctrine, the reader can debate how effective the counterinsurgency could have been and evaluate the effectiveness of contemporary COIN doctrine.

\begin{tabular}{|c|c|c|c|c|l|}
\hline 15. SUBJECT TERMS & & $\begin{array}{c}\text { 17. LIMITATION OF } \\
\text { ABSTRACT } \\
\text { 16. SECURITY CLASSIFICATION OF: }\end{array}$ & $\begin{array}{c}\text { 18. NUMBER } \\
\text { OF PAGES }\end{array}$ & $\begin{array}{c}\text { 19a. NAME OF } \\
\text { RESPONSIBLE PERSON }\end{array}$ \\
$\begin{array}{c}\text { S. REPORT } \\
\text { unclassified }\end{array}$ & $\begin{array}{c}\text { b. ABSTRACT } \\
\text { unclassified }\end{array}$ & $\begin{array}{c}\text { c. THIS PAGE } \\
\text { unclassified } \\
\text { Report (SAR) }\end{array}$ & $\mathbf{2 1}$ & \\
\end{tabular}




\section{Disclaimer}

The views expressed in this academic research paper are those of the author and do not reflect the official policy or position of the US government or the Department of Defense. In

accordance with Air Force Instruction 51-303, it is not copyrighted, but is the property of the United States government. 


\section{TABLE OF CONTENTS}

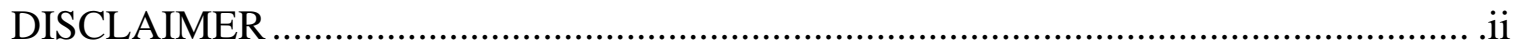

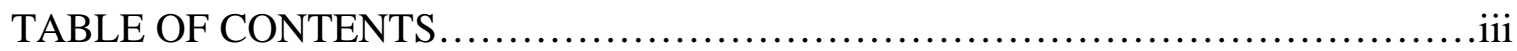

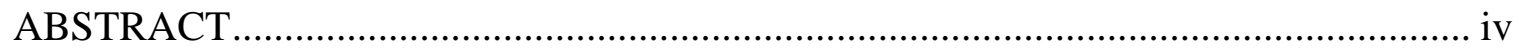

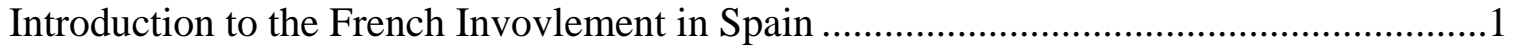

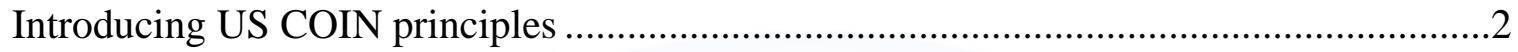

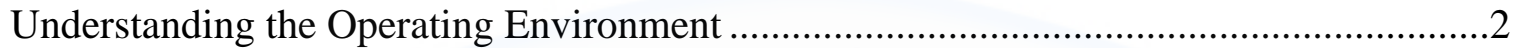

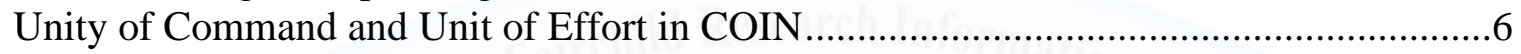

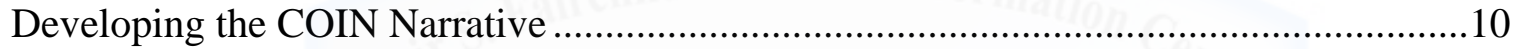

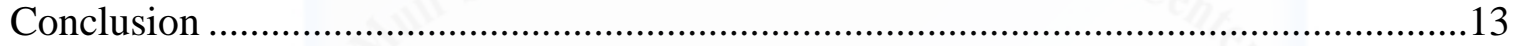

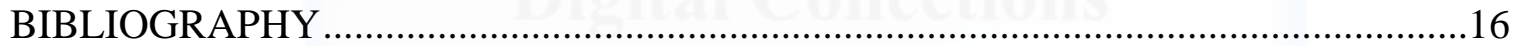




\begin{abstract}
This paper attempts to portray the failures of French counterinsurgency efforts in Spain during the Napoleonic Wars in relation to US COIN tenets of understanding the Operating Environment, Unity of Command and Unity of Effort, and developing the COIN narrative. A truly effective COIN strategy encompasses a whole-of-government approach but the tenets of primacy of politics and securing the population would exceed the scope of this paper. The method of research involved a comparison of these modern COIN principles with historical examples from the time of Napoleon's actions in Spain. At the conclusion of the research, the key findings were of no surprise. Napoleon, King Joseph Bonaparte, and his commanders in the field failed to grasp the sociocultural issues motivating the insurgents, clumsily attempted to establish unity of command that failed to achieve a unified COIN effort against the insurgency, and developed a narrative that countered an effective COIN strategy. In conclusion, by comparing historical examples to modern doctrine, the reader can debate how effective the counterinsurgency could have been and evaluate the effectiveness of contemporary COIN doctrine.
\end{abstract}




\section{Introduction}

Sitting in exile on St. Helena, Napoleon Bonaparte contemplated on how he came to be on this remote island in the Atlantic Ocean after dominating all of Europe for 20 years. Despite what was surely delusional rhetoric to justify errors and mismanagement of his vast French Empire, the truth worked its way out. A cause that Napoleon himself admitted to contributing greatly to the demise of his Empire was not the climactic battle of Waterloo, or even the disastrous invasion of Russia that decimated the flower of the imperial fighting spirit of which both pitted him against formidable conventional military powers. Napoleon references a theater that did not include much of an intimidating military as influential in bringing him to his current predicament. Spain, thought of as a backwater and often an afterthought compared to more pressing diplomatic and military challenges from the four powers of England, Austria, Prussia, and Russia, was specifically described by the Corsican as bringing forth the fall of Napoleonic France. ${ }^{1}$ This unending struggle from 1808-1814 gave rise to the modern guerilla war that continued to bleed the empire of irreplaceable resources. ${ }^{2}$ France's attempt to conduct counterinsurgency methods in Spain would ultimately fail and in light of recent conflicts can illustrate the necessity of modern US doctrine.

Counterinsurgency (COIN) has been a modern day buzzword following US experiences in Iraq and Afghanistan. The US military has developed a joint COIN doctrine that encases principles that have been battle tested in two wars over the last ten years. These tenets can be the lens through which to focus on French COIN strategy in Spain and how these failures festered into an untenable situation that led to ultimate disaster. French COIN strategy in Spain between 1808 and 1814 failed to achieve any sustainable success and caused an enormous strain in men and material on the Napoleonic Empire. These failures can best be understood through 
examination of French efforts through key modern principles of COIN practiced by US joint forces: understanding the operating environment, setting the conditions for unity of command to achieve unity of effort, and developing an effective COIN narrative.

After the French invasion of Spain in 1808 to quell any uncertainty of the country's allegiance to the empire and to eliminate Portugal as a weak link in his Continental System, Napoleon thought that this historical ally since 1796 would only acquiesce to his demands and intent to use the country as a means to further the imperial whims with soldiers, treasure, and ships. ${ }^{3}$ However, following the battle of Bailen in July 1808 and the subsequent surrender of a French army to a ragtag group of Spanish regular soldiers and irregulars under a rising star in the French army, General Dupont, it was apparent that Spain would not be so easily conquered. ${ }^{4}$ Napoleon himself entered the fray and with his usual style swept all before him and restored his brother Joseph to the throne in Madrid. After only staying a few months, other issues such as a potential coup in Paris and a mobilizing Austria beckoned him to leave Spain to Joseph and his marshals. ${ }^{5}$ He never returned to the theater that he would later admit as bringing about his demise. What transpired later could only be considered as a bumbling attempt at counterinsurgency that Napoleon stated, "divided my forces, multiplied my obligations, [and] undermined my morale". ${ }^{6}$ Napoleon and his marshals failed to understand the operational environment that French forces would operate in and this shaped the course for future failures in COIN strategy.

\section{Understanding the Operating Environment}

The operating environment that the French found themselves once they crossed into Spain was unlike Napoleon's previous wars in the more developed portions of northeastern Europe. From an infrastructure stand point, he had previously benefited from an ancient road 
network developed by the Romans in central Europe to move troops from place to place at the fastest possible speeds. A lack of this developed infrastructure combined with terrain much different than previously experienced by French troops became vulnerabilities susceptible for exploitation by the Spanish insurgents. The French imperial might encountered numerous mountain chains which led to restrictions on the use of cavalry and artillery that canalizing their forces along poorly developed roads. ${ }^{7}$ The advantages of the French army in tactics, numbers, and technology were negated by the difficult geography - especially in provinces like Navarre. ${ }^{8}$ Napoleon himself encountered the difficulties of moving in pursuit of the enemy during his attempt to bottle up Moore’s British force in $1808 .{ }^{9}$ His ability to visualize the terrain to his advantage had always been a key factor in his campaigns but during this encounter the British escaped to fight another day which later proved to be a disastrous enabler of the Spanish insurrection to French rule. ${ }^{10}$ The more pronounced issue that was allowed to stagnate and impact every aspect of French COIN efforts was the knowledge on the sociocultural factors, a sub-tenet of the operating environment, which inspired the insurgency.

US doctrine highlights sociocultural knowledge as a key factor in understanding the operational environment. This was not a French priority in 1808 and even as the insurgency spread and gained momentum it was not wholly adopted as a tool to counter insurgent methods. Joint Publication 3-24 states, “cultural norms and traditions are often linked to political agendas and ideologies”. ${ }^{11}$ Napoleon and his marshals were generally consistent in the fact that grasping these cultural motivations of a nation's populace was never a concern but the Spanish situation would require a different approach. Napoleon had not encountered a full blown insurgency since the formation of the empire in 1804 and his opponents had consisted of more conventional armies that once vanquished would capitulate and agree to his demands. ${ }^{12}$ After Napoleon's 
departure for Paris in January 1809 following his quick visit to put things to rights, the Spanish army was no longer an entity to threaten French military might - that now fell to the individual Spanish fighter. ${ }^{13}$ Due to the varying cultures that had developed in Spain, there were numerous motivations to fight the French other than to repel any invader. In Navarre for example, "the dispersion of the population, the unarticulated peasant economy, and the tradition of strong village government" inspired the guerrillas to mount one of the most successful insurgencies against the military hegemon of the European continent. ${ }^{14}$ Yet, the macro viewpoint on allegiance to the Bourbon crown as a motivation for insurgency cannot be overlooked. Spain, historically an absolute monarchy, had previously fought French revolutionary armies from 1793-1795 in a war popular to the Spanish people but in the end was forced to an alliance when defeat was inevitable. ${ }^{15}$ Despite the cultural differences within the Spanish provinces, the defense of their hereditary monarchy as a unifying catalyst to resist was underestimated by Napoleon and his marshals and is an example of French failure in understanding the operational environment.

Nothing galvanized the Spanish people more than the defense of the rightful heir to the throne of Spain. JP 3-24 states, "understanding the OE [operating environment] requires an understanding of the factors that shape the decision making and associated behavior of significant actors” ${ }^{16}$ The events on 2 May 1808 in Madrid and subsequent uprisings reflect French failures in grasping the factors that shaped the decision by the Spanish people to fight. Upon seeing Marshal Murat and French forces occupy Madrid there was a sentiment that "there was still hope in the air, the hope that the French emperor was establishing his armed might in Spain to help chase the detested Godoy and aid Fernando”. ${ }^{17}$ King Ferdinand represented the restoration of the glory of Spain and a turning away from the decadence and corruptness by the former Prince of Peace Godoy. ${ }^{18}$ Yet once the people came to the realization that Ferdinand 
would not remain their King they sprang into action. The end result was a bloody repression of the uprising and numerous executions that followed which led to roughly 1,000 French and Spanish dead. ${ }^{19}$ The news of the abdication of Ferdinand and the violent events in the Spanish capital spread throughout the area and encouraged the insurgency to form. In the capital of Aragon, Zaragoza, Ferdinand was viewed as a "modern Moses” that would bring about more prosperous times and therefore they resisted once the news out of Madrid was relayed and were subsequently put under siege by French troops under General Lefebvre-Desnoettes. ${ }^{20}$ In Gerona, northeastern Spain, the garrison of the city began resisting French occupation motivated by their allegiance to King Ferdinand VII and held out until their surrender in December 1809 thus becoming one of the last organized resistance in that area prior to the insurgency becoming the main effort against French occupation. ${ }^{21}$ These events point to the fact that Napoleon miscalculated the impact of removing the Bourbon King and unintentionally planted the seeds for national resistance to his occupation of their sovereignty. Though King and Country were proven motivators, the Spanish cultural value on local government would prove just as powerful a force for France to contend with.

A micro viewpoint on the sociocultural influences to rebellion, which was alluded to earlier by Tone, was the Spanish people's value on local self-governance. The fact that the first significant insurgencies occurred in the cities that contained the political, administrative, and military authorities of the region regardless of population density is indicative of how much local issues mattered. ${ }^{22}$ The importance of this cultural aspect to the uprising was reflected by an actual French success story. While the majority of French leaders, including Napoleon, did not consider the sociocultural motivations of their opponents in Spain, not all were blind to their operating environment. Considered one of the only COIN successes in Spain, Marshal Suchet's 
administration of the province of Aragon in the northeast of Spain attempted to address some of the sociocultural factors that were specific to the area - particularly village government. Once the conventional fight was concluded and he was proclaimed the French governor of the province, Suchet left the previous local government officials who had proved to be efficient in place to assist in police, tax collection, and other administrative duties. ${ }^{23}$ The local populace in the region witnessed this stabilizing policy and therefore Suchet helped address the issue of village self-governance that the Spanish valued so greatly. He remarked that the Arragonese, 'are proud, obstinate, jealous of their liberty...fancy that they possess more physical strength, and spring from nobler blood, than the Castillians, because they are less inclined to bend to their

superiors. ${ }^{24}$ His words reflect the fact that he had conducted some sort of study on the Spanish people of Aragon and their motivations to resist French rule. He then could institute policy that would assist in curbing the insurgent threat to his policies and forces. Suchet was starting the process of understanding his operational environment and this would prove to be the only bright spot in an otherwise gloomy enterprise due to a lack of cooperation among the French marshals reflecting one of the most damaging failures in COIN strategy - unity of effort. His performance addressing the self-governance issue was not the norm. The reason that his policies and example of success was not imitated by all French leaders has to do with the particular command relationships and lack of a unity of effort for COIN operations.

\section{Unity of Command and Unity of Effort}

The relationship between Napoleon and Joseph undermined French counterinsurgency strategy and ensured their efforts would not succeed. Once Napoleon restored his brother Joseph to the throne, and flooded Spain with his marshals, he established a condition that would lead to uncoordinated efforts in suppressing the Spanish insurrection. Napoleon's incessant obsession 
with control would not allow him to delegate any command authority to Joseph over his marshals in Spain which weakened French COIN efforts. According to US joint doctrine, unity of command is not always feasible but unity of effort is absolutely necessary in coordinating an effective strategy that does not allow insurgents to exploit weaknesses in the force. ${ }^{25}$ When Napoleon left Spain never to return he had established Joseph as the sovereign ruler in Spain once again yet refused to allow him to dictate French COIN policy and instead prosecuted the war from afar. ${ }^{26}$ These actions only served to undermine King Joseph's attempts to establish his government's legitimacy to pursue COIN policies. Moreover, even though Napoleon was clearly the brightest military mind of the age whereas his brother was inexperienced in waging war, the most dangerous effect that this had on French efforts was confusion.

While Joseph would attempt to urge marshals to action, Napoleon was constantly sending orders that often conflicted with the French king of Spain. Though this was confusing in itself, many times the distances traveled by the couriers through enemy territory increased the chances that French forces were operating in the blind. ${ }^{27}$ This issue was paramount in the inefficiency that occurred during Valencian campaign in 1809 by Marshal Suchet ordered by King Joseph. While Suchet attempted to obey Spain’s sovereign, Napoleon was sending orders that proclaimed the marshal "governor-general" of Aragon with autonomy to carry out his orders removed from Joseph's influence. ${ }^{28}$ This did not cause any direct military failure but it did block any attempt at a coherent unity of command to conduct the counterinsurgency strategy.

Napoleon's directing the war without context of the situation in Spain produced a tenuous relationship between his marshals and King Joseph. While Joseph tried to implement operations in his kingdom and take the reins from his brother, French commanders would only follow the orders of the Emperor. ${ }^{29}$ When the marshals received orders from Joseph they would only adhere 
to those that were beneficial to them. ${ }^{30}$ However, nothing undermined and delegitimized Joseph's reign more than when, in 1810, Napoleon fragmented Spain into military districts that were not beholden to Joseph's commands. ${ }^{31}$ Prior attempts by the French king of Spain to conduct his own COIN strategy, as in the conquest of Andalusia province, were null upon Napoleon's decree. All the previous efforts to legitimize Joseph, tame the marshals to do his bidding, and unify French COIN policy despite Napoleon’s distant meddling were for naught. Not only had Napoleon made his brother a spectator in the insurgency but he ensured that there would be no unity of effort among the marshals that were now the government over vast areas of Spain.

The nature of the marshalate system of the Napoleonic Empire contributed to a lack of unified effort in waging COIN operations in Spain. Napoleon fostered a competitive spirit between his marshals all the while ensuring that strategic decisions were his alone to make and these factors directly contributed to a lack of unity of effort in Spain. The competitive traits that defined the marshalate enabled a brand of leadership to emerge that was encouraged only with limitations during the Revolution for fear of someone much like Napoleon rising to eminence. By proclaiming an outstanding French general a marshal of the French Empire, Napoleon was displaying a trust in that particular officer to follow his directives and, more importantly, bonding that subordinate to his destiny. ${ }^{32}$ By placing himself as the sole decision maker in who is rewarded with such a title, Napoleon created a self-perpetuating beast that refused to cooperate or display any synergistic characteristics with each other. Some marshals performed well when directed by their master and some even demonstrated a capability for independent command like Massena and the Army of Italy during the siege of Genoa in $1800 .{ }^{33}$ Though not one of the glorious victories by the Grand Armée, it demonstrated Massena’s resolve and competency 
under adverse conditions that would have been hard to replicate. Yet there existed an uncoordinated effort in the peninsula due to the competitive traits of the marshals.

The lack of cooperation between the marshals, along with a lack of a shared strategic goal, only served to enable the insurgents to exploit these weaknesses. Even their motivations negated a coherent COIN strategy like Soult's desire for the invasion of Andalusia in 1809 based on autonomous power and the treasures that would no doubt be found. ${ }^{34}$ Even when motivations were not suspect the competitive spirit ingrained within the imperial marshals of France fueled an unwillingness to see a rival succeed. Indicative of this fact is when, "almost the last act of Bessieres was to advise Marmont not to march down to Badajoz to help Soult, and he gave this advice, not on strategical grounds, but simply because he detested the Viceroy of Andalusia.”35 Though Marmont did not heed Bessieres advice and instead rushed to support his compatriot, the temptation to leave a perceived competitor to his fate portrays the systemic problem of a competitive marshalate waging COIN operations.

Not only were French commanders uncooperative with each other their policies were unique to their specific region and not linked to a unified COIN strategy. When insurgents within Navarre province began to impact imperial forces and demand a response, the French governor negotiated with the Spanish insurgent leader which destabilized the border of Suchet's Aragon with Navarre causing him to react in force. ${ }^{36}$ Suchet even suggests that the situation was allowed to develop due to a poor administration by the French government in Navarre. ${ }^{37}$ Not only did the French military provinces have uncoordinated COIN policies, a unique situation developed that capitalized on the marshalate's competitive spirit which contributed to a lack of a unity of effort. When Napoleon created the military districts of Spain in 1810, alluded to earlier, he indirectly refocused the French commander's efforts from COIN to provincial 
administration. ${ }^{38}$ Taxation and providing for the French war effort across Europe became more important than defeating the Spanish insurgents. ${ }^{39}$

French unity of effort was never realized due to Napoleon's desire to withhold command authority which failed to legitimize King Joseph’s government and create friction between his brother and commanders in the field. This caused confusion among the marshals and inefficiencies in the field. Unity of command could be argued was achieved through Napoleon's control from afar, but unified action was never grasped. Also, the competitive nature of the imperial marshalate caused an uncoordinated approach to combating the insurgents once Napoleon split Spain into military districts to feed his insatiable war machine. While French forces were never fully coordinated in conducting COIN, they were consistent in developing a narrative that was counterproductive to quelling the insurgency.

\section{Developing the COIN Narrative}

Developing a narrative for counterinsurgency operations is critical to attacking one of the insurgent's main centers of gravity in the local populace. ${ }^{40}$ The effect is to demonstrate that COIN forces are "just and irresistible....legitimizing counterinsurgent actions and delegitimizing the insurgency". ${ }^{41}$ The effort should be to win over the locals to the COIN cause thereby removing their support to the insurrection. French forces in Spain created a narrative that ran counter to achieving these goals outlined in US joint publication 3-24. Upon invading Spain in 1808 under the guise of conquering Portugal, Napoleon’s forces institutionalized harsh treatment to the Spanish people and demonstrated that their values, customs, and sovereignty were subordinate to the whims of the Emperor. Nothing demonstrated this more than the brutality while suppressing the unrest following French occupation, execution of military operations, and perceptions of French intentions that prevailed despite being proven fictional. 
Condition for brutality occurred rapidly throughout Spain once it was perceived that the French were not passing through only to invade Portugal or to secure their beloved Ferdinand on the Spanish throne. French leaders would quickly allow their actions to undermine an effective COIN narrative that would win over the population away from the cause of the insurgents. One of the first events that French leaders bungled in establishing a strategic message to the people was Marshal Murat's execution of troublemakers and civilians following the uprising in Madrid on May 2, 1808. Murat's proclamation to his soldiers and citizens of Madrid stated what had occurred and that "French blood has been spilled. It demands vengeance." ${ }^{42}$ This is not a narrative that champions the law abiding civilians but threatens brutal force on the whole. As the insurgency gained momentum, the French had difficulties separating the insurgents from the civilians and rarely distinguished between the two.

Another example of the French developing a ruinous COIN narrative occurred when one of Napoleon's best marshals, Jean Lannes, presided over "the Stalingrad of the Peninsular War" in his siege of Saragossa from fall of 1809 until February $1810 .{ }^{43}$ He conducted a very methodical and bloody advance through the strongly defended city eventually raising the daily casualty rate to $600-700$ a day by the end of the siege. ${ }^{44}$ After the city's surrender to Marshal Lannes, it was estimated that 54,000 Spanish soldiers and civilians were killed compared to 4,000 French losses. ${ }^{45}$. With the news of the bloody events, that included not only insurgents and former regular army soldiers but women and children, the civilian population perceived that France's aim was the complete subjugation of the Spanish people and their way of life. Events like Saragossa increased the legitimacy of the insurgency especially after the Spanish resistance leader Palafox was treated as a war criminal by the French instead of a captured enemy officer performing his duty for his nation. ${ }^{46}$ Not only were French military actions creating a negative 
COIN narrative but the perceptions of French intentions created their own strategic message with the civilian population before any major operation was underway.

Napoleon's reputation as a drain on a conquered nation's resources and manpower to feed his insatiable war machine had preceded his forces entry into Spain. He had captivated Western Europe with his military exploits that humbled traditional powers like Austria and Russia. Wars required manpower and conquered nations were routinely subjected to conscription as replacements to the dead and wounded littered across the continent. The common Spanish people understood this fact and as French troops began to move throughout Spain in 1808 fear began to spread that the army "had brought in its baggage train thousands of manacles to seize the young and force them into Napoleon's army in the north of Europe" ${ }^{47}$ The reason that the worry of conscription had such a powerful effect on the Spanish was that there existed a historical precedent for an extreme revulsion to military service and even more so for mandatory enlistment that predated the events of the French Revolution of $1789 .^{48}$ This aversion to conscription and army life was one reason to the poor state of Spanish forces when Napoleon sent his armies across the Pyrenees. ${ }^{49}$ This rumor made it to the ears of the newly proclaimed King of Spain, Joseph Bonaparte, who attempted to quell the reaction to no avail for the fear of French conscription served as a prime inspiration to resist in the form of insurrection to foreign rule. ${ }^{50}$ Yet, Joseph would attempt to correct the COIN narrative that been constructed to France's detriment.

The operation to conquer Andalucía in 1810 was not purely for military gain but to develop a narrative to legitimize King Joseph and the COIN effort. ${ }^{51}$ To his credit the French king of Spain had made attempts to rule in a benevolent manner initially and achieved limited success to countering the insurgent mentality in the capital where he spent most of his time. ${ }^{52}$ 
Therefore, the invasion of Andalucía provided an opportunity to send a message to the people of Spain. The idea was to present the new French king and counter the insurgent narrative that had developed. Joseph's efforts were steeped in religious overtones to disparage claims the French would abolish Catholicism and his travels laced with propaganda were immensely successful. ${ }^{53}$ Yet despite the success the French COIN narrative did not reach Cadiz, which was the heart of the insurgency, and the unrest was allowed to fester until outside assistance from Great Britain created an untenable situation for the French. ${ }^{54}$

\section{Conclusion}

Napoleon received more than he ever thought possible when he decided to subjugate the Spanish crown, and place his brother on the throne, enroute to maintain his continental system by closing Portugal's ports off to British use. The type of warfare that his troops were subjected to was unlike any seen during the Grand Armée’s crushing of the powerbrokers of Europe back and forth across the continent. The French Army was the most powerful force on land and had never met a defeat when Napoleon commanded it. Even during his brief interlude into Spain in late 1808 he vanquished all before him and reversed the setbacks of the French. His success would ultimately be the catalyst for his defeat in the peninsula. The Spanish resulted to resistance by way of insurgency and guerilla tactics due to their inability to counter the French in the conventional fashion. As French commanders attempted to come to grips with the uprisings while conducting operations against British forays from Portugal, counterinsurgency efforts were generally mismanaged and unsuccessful. In comparison to recent US history with counterinsurgency in Iraq, the world's greatest military was a technologically advanced replica of the Grand Armée in Spain. As a result of Operation Iraqi Freedom, joint COIN doctrine includes tenets that provide a framework for developing an effective COIN strategy. By 
understanding the operational environment, establishing unity of command to achieve unity of effort, and developing the proper COIN narrative, counterinsurgency forces will have the means necessary to wage effective operations against their opponent. Napoleon's forces in Spain from 1808-1814 failed to grasp these tenets and incurred an average loss of 300 men a day attempting to conduct a failing COIN strategy. ${ }^{55}$ As the British began to pressure the French in the region and Napoleon's ambition took the lives of millions across Europe fighting Emperors and kings, the Spanish peasants' contributions can go down in history as a comparison to the biblical David and Goliath of epic proportions. Their resistance directly contributed to one of the greatest military commanders in world history wasting away on an island never to return alive to his native soil.

1 Owen Connelly, Blundering to Glory: Napoleon's Military Campaigns. (Lanham, MD: Rowman and Littlefield Publishers, Inc., 2006), 117.

2 John Lawrence Tone, The Fatal Knot: The Guerrilla War in Navarre and the Defeat of Napoleon in Spain. (Chapel Hill, NC: University of North Carolina Press, 1994), 4. 3 Norman Dale Eaton, "Spanish Military Contributions in the Peninsular War” (Master’s Thesis, University of Wisconsin, 1956), 13-14.

4 Richard Humble, Napoleon’s Peninsular Marshals (New York, NY: Taplinger Publishing Co., Inc., 1973), 69. 5 Connelly, Blundering to Glory, 129.

6 Tone, The Fatal Knot, 3.

7 Ibid., 7.

8 Ibid., 10.

9 Humble, Napoleon's Peninsular Marshals, 93.

10 Connelly, Blundering to Glory,

11 United States Joint Publication 3-24, Counterinsurgency, 22 November 2013, III-8.

12 Humble, Napoleon's Peninsular Marshals, 63.

13 Eaton, "Spanish Military Contributions in the Peninsular War”, 27.

14 Tone, The Fatal Knot, 7.

15 Eaton, "Spanish Military Contributions", 5.

16 JP 3-24, IV-1.

17, Gabriel, H Lovett, Napoleon and the Birth of Modern Spain: The Challenge to the Old Order. (New York, NY: New York University Press, 1965), 133.

18 Ibid., 135.

19 Ibid., 149.

20 Tone, The Fatal Knot, 60-61. 
21 Humble, Napoleon's Peninsular Marshals, 116-117.

22 Ronald Fraser, Napoleon's Cursed War: Popular Resistance in the Spanish Peninsular War (London and New York, UK and NY: Verso, 2008), 83.

23MAJ Jean-Philippe Rollet, "Conqueror and Administrator: Civil and Military Actions of Marshal Louis-Gabriel Suchet in the Spanish Province of Aragon 1808-1813” (United States Marine Corps Command and Staff College, 2008), 8-9.

24 Ibid., 9.

25 JP 3-24, III-15.

26 Humble, Napoleon's Peninsular Marshals, 93.

27 Eaton, “Spanish Military Contributions”, 79.

28 Ibid., 80.

29 Michael A. Bonura, “The Beginning of the End in Spain: Napoleon’s Decision to Make War Pay for War and the Creation of the Military Districts of Spain in 1810” (Arlington, VA: Society for Military History, 2012), 1-2.

30 Ibid., 3.

31 Humble, Napoleon's Peninsular Marshals, 122.

32 Humble, Napoleon's Peninsular Marshals, 11.

33 Ibid., 32-33.

34 Ibid., 118.

35 A.G. MacDonnell, Napoleon and His Marshals. (New York, NY: The Macmillan Company, 1934), 232.

36 Eaton, “Spanish Military Contributions”, 78.

37 Ibid.

38 Bonura, “The Beginning of the End in Spain”, 10.

39 Ibid., 10-11.

40 JP 3-24, III-9.

41 Ibid.

42 Lovett, Napoleon and the Birth of Modern Spain, 147.

43 Humble, Napoleon's Peninsular Marshals, 99.

44 Ibid., 100

45 Ibid.

46 Ibid.

47 Fraser, Napoleon's Cursed War, 84.

48 Charles J. Esdaile, The Spanish Army in the Peninsular War. (Manchester, UK: Manchester University Press, 1988), 9.

49 Ibid.

50 Fraser, Napoleon's Cursed War, 84.

51 Esdaile, Outpost of Empire: The Napoleonic Occupation of Andalucía, 1810-1812. (Norman, OK: University of Oklahoma Press, 2012), 133.

52 Ibid., 134.

53 Ibid., 185.

54 Ibid.

55 Humble, Napoleon's Peninsular Marshals, 67-68. 


\section{Bibliography}

Bonura, Michael A. “The Beginning of the End in Spain: Napoleon’s Decision to Make War Pay for War and the Creation of the Military Districts of Spain in 1810” (Arlington, VA: Society for Military History, 2012).

Connelly, Owen, Blundering to Glory: Napoleon's Military Campaigns. (Lanham, MD: Rowman and Littlefield Publishers, Inc., 2006).

Humble, Richard, Napoleon's Peninsular Marshals. (New York, NY: Taplinger Publishing Co., Inc., 1973).

MacDonell, A.G., Napoleon and His Marshals. (New York, NY: The Macmillan Company, 1934).

Lovett, Gabriel, H. Napoleon and the Birth ofModern Spain: The Challenge to the Old Order. (New York, NY: New York University Press, 1965).

Eaton, Norman Dale, “Spanish Military Contributions in the Peninsular War.” Master’s thesis, University of Wisconsin, 1956.

Esdaile, Charles J., The Spanish Army in the Peninsular War. (Manchester and New York, UK and NY: Manchester University Press, 1988).

Esdaile, Charles J., Outpost of Empire: The Napoleonic Occupation of Andalucía, 1810-1812. (Norman, OK: University of Oklahoma Press, 2012)

Fraser, Ronald, Napoleon's Cursed War: Popular Resistance in the Spanish Peninsular War. (London and New York, UK and NY: Verso, 2008).

Rollet, Jean-Philippe MAJ, “Conqueror and Administrator: Civil and military Actions of Marshal Louis-Gabriel Suchet in the Spanish Province of Aragon 1808-1813”. United States Marine Corps Command and Staff College, 2008.

Tone, John Lawrence, The Fatal Knot: The Guerrilla War in Navarre and the Defeat of Napoleon in Spain. (Chapel Hill, NC: University of North Carolina Press, 1994).

United States Joint Publication 3-24, Counterinsurgency, 22 November 2013. 